\title{
ИСПОЛЬЗОВАНИЕ РЕГИОНАЛЬНОГО МАТЕРИАЛА В ПРОЦЕССЕ ИЗУЧЕНИЯ ИНФОРМАТИКИ ДЛЯ АКТИВИЗАЦИИ ПОЗНАВАТЕЛЬНОЙ ДЕЯТЕЛЬНОСТИ УЧАЩИХСЯ
}

\section{USE OF REGIONAL LEARNING MATERIAL IN THE PROCESS OF TEACHING COMPUTER SCIENCE TO ENHANCE COGNITIVE ACTIVITY OF STUDENTS}

\section{Dukhovnikova}

A. Korol

Summary: The article analyses the Khabarovsk Territory's experience of creatinginteractive educational resources with regional content when teaching different general education subjects (computer science as a particular example). The possibility and expediency of the use of the regional material in the process of teaching computer science for enhancing cognitive activity of students is being substantiated.

Keywords: enhancement of cognitive activity, computer science, educational resources with regional content, regional educational content.

\section{Духовникова Ирина Юрьевна} старший преподаватель, ФГБОУВО "Тихоокеанский государственный университет", г. Хабаровск

Король Александр Михайлович

к.n.н., nрофессор, ФГБОУ ВО "Тихоокеанский государственный университет", г. Хабаровск kor_kor2001@mail.ru

Аннотация: В статье анализируется опыт Хабаровского края по созданию интерактивных обучающих ресурсов регионального содержания при изучении различных общеобразовательных предметов (на примере школьного курса информатики).

0босновывается возможность и целесообразность использования регионального материала в процессе изучения информатики для активизации познавательной деятельности учащихся.

Ключевые слова: активизация познавательной деятельности, информатика, ресурсы регионального содержания, региональный образовательный контент.

\section{интерактивные ресурсы}

- интерактивная обучающая игра-квест "Путешествие по краю Вселенной" (общественно-научные предметы, естественнонаучные предметы),

- "Интерактивная экскурсия по краеведческому музею" (общественно-научные предметы, естественнонаучные предметы),

- "Интерактивная экскурсия по Дальневосточному художественному музею" (общественно-научные предметы, дисциплины предметной области "Искусство"),

- "Интерактивная экскурсия по Военно-историческому музею Краснознаменного Дальневосточного военного округа" (общественно-научные предметы),

- пособие для начальной школы "Времена года" (учебный предмет "Окружающий мир"),

- аудиокнига для начальной школы "Сказки народов Севера" ("Родной язык и литературное чтение"),

- "Азиатско-Тихоокеанский регион: история, география, экономика" (общественно-научные предметы),

б) интерактивные ресурсы для предметных областей и отдельных дисциплин

- "Внешняя политика СССР на Дальнем Востоке в первой половине XX века" ("История России" и 
"Всеобщая история"),

- "Экономическая и социальная география Хабаровского края" ("География"),

- "Изучаем восточные языки и Хабаровский край" ("Иностранный язык"),

— "О любимом крае на английском" ("Иностранный язык"),

— "Физическая география Хабаровского края" ("География"),

- "Дальний Восток в средние века" ("История"),

- "Безопасность школьника и Хабаровский край" ("ОБЖ"),

— "Физика и Хабаровский край" ("Физика"),

- "Информатика и Хабаровский край" (дисциплины предметной области "Математика и информатика").

Разработка последнего в приведённом списке электронных ресурсов пособия для изучения информатики является уникальным для Хабаровского края опытом, поскольку принято считать, что школьный курс информатики является слабо "регионализируемым". Действительно, перед разработчиками ресурса стояла непростая задача изложить основы школьного курса информатики с опорой на конкретные примеры из жизни школьников, их непосредственного окружения. При этом учащиеся, изучая основы информатики с использованием электронного пособия, должны опосредовано получить возможность расширить свои знания и кругозор о Хабаровском крае, своём родном городе, посёлке.

Остановимся подробно на структуре и возможностях электронного учебно-справочного пособия "Информатика и Хабаровский край" для активизации познавательной деятельности школьников.

Пособие предназначено для учащихся общеобразовательных школ Хабаровского края и содержит учебный материал, гиперссылки на внешние ресурсы, а также задачи, разработанные на основе информации о фактах, явлениях и событиях, окружающих повседневно жителей Хабаровского края. Таким образом, кроме изучения информатики пособие помогает узнать много нового о родном крае. Пособие может быть использовано как источник дополнительной справочной информации в рамках школьного курса информатики, в качестве основы межпредметных факультативных учебных курсов, как материал для самостоятельного изучения школьниками, а также в системе дополнительного образования детей. В качестве дополнительного информационного ресурса при планировании и проведении занятий по информатике пособие может быть полезно учителям общеобразовательных школ, преподавателям учреждений начального и среднего профессионального образования.

Пособие разработано ООО «Портал Хабаровск» (г. Хабаровск) по заказу министерства образования и науки Хабаровского края.
Ресурс зарегистрирован в Депозитарии электронных изданий федерального государственного унитарного предприятия "Научно-технический центр "Информрегистр" (номер государственной регистрации 0321502010) и включён в фонды и каталоги ведущих библиотек Российской Федерации.

Содержание пособия включает теоретический материал по избранным разделам школьного курса "Информатика и ИКТ", вопросы и задачи, интерактивный словарь, словарь компьютерного сленга, фотографии, схемы, иллюстрации.

Системные требования: Windows 7 и выше, процессор не менее 2,8ГГц.

Пособие оформлено и структурировано в виде электронной книги с выделением оглавления, разделов, подразделов, возможностью листинга страниц.

\section{Структура пособия:}

1. Информация.

1.1. Понятия: информатика, информация, данные.

1.2. Классификация и свойства информации.

1.3. Информационные процессы.

1.4. Количество информации.

1.5. Представление (кодирование) данных.

2. Системы счисления.

2.1. Классификация систем счисления.

2.2. Непозиционные системы счисления.

2.3. Позиционные системы счисления.

2.4. Перевод чисел из одной системы счисления в другую.

3. Алгебра логики.

3.1. Основные понятия алгебры логики.

3.2. Операции в алгебре логики.

3.3. Логические выражения и законы.

3.4. Способы задания логических функций.

4. Теория графов.

4.1. Множества.

4.2. Основные понятия теории графов.

4.3. Связность графов.

4.4. Задание графов.

4.5. Кратчайший путь в графе.

В пособии при раскрытии понятий "информация", "данные", "информационные процессы", "количество информации" широко используется материал, связанный с Хабаровским краем.

Например, объясняя понятие "данные", указывается, что с точки зрения информатики данные - это результат фиксации (записи) или отображения информации на каком-либо носителе. Иными словами, данные - это сведения, зарегистрированные на некотором носителе.Для иллюстрации этого определения приводится скриншот монитора аэропорта города Хабаровска с изображением онлайн табло вылетающих рейсов. Сам список рей- 
сов - номера, пункты назначения, время отправления и т.д. - это информация, которая представлена в виде данных, хранящихся на сервере аэропорта.

Школьникам предлагается с учётом своего жизненного опыта самим привести другие примеры публичной информации, представленной в виде данных, размещённых на некоторых носителях. Данное задание, традиционно, вызывает живой интерес и обсуждение учащихся.

Для объяснения классификации и свойств информации в пособии используются ссылки на внешние ресурсы - сайты ФГБУ "Дальневосточное управление по гидрометеорологии и мониторингу окружающей среды", АО "Амурское пароходство", государственная телевизионная и радиовещательная компания "Дальневосточная", ООО "Губерния Он-лайн", ООО "Рекламноинформационный центр "Деловой Хабаровск", краевое государственное бюджетное научное учреждение культуры" Дальневосточная государственная научная библиотека", Хабаровский филиал компании "Ростелеком" и другие известные школьникам Хабаровского края и часто используемые ими в быту web-pесурсы.

В качестве иллюстрации понятий "объективность" и "субъективность" информации приводится пример фотографии лошади и её изображения на петроглифе на поверхности базальтовых валунов. Понятие объективности информации является относительным. Более объективной принято считать ту информацию, в которую вносится меньший субъективный элемент. Например, принято считать, что в результате наблюдения фотоснимка природного объекта образуется более объективная информация, чем в результате наблюдения рисунка того же объекта, выполненного человеком. Данный пример с наскальными изображениями побуждает школьников ознакомиться с историей открытия петроглифов Сикачи-Аляна на месте древнего нанайского стойбища в Хабаровском районе Хабаровского края, использовать полученные знания на уроках истории Дальнего Востока.

Следует отметить особую ценность приведенной в пособии подборки задач регионального содержания для активизации познавательной деятельности школьников. Приведём наиболее интересные из них.

Задача 1. Известно, что одноклассники школьников из Комсомольского муниципального района организовали туристическую поездку в один из соседних районов Хабаровского края. Сколько бит информации содержит сообщение о том, что школьники выехали в Ванинский муниципальный район?

Задача 2. Каково минимальное количество бит, которым можно закодировать все муниципальные районы и городские округа Хабаровского края, если каждому муниципальному району (городскому округу) сопоставить уникальное число:
1 - городской округ "Город Хабаровск";

2 - городской округ "Город Комсомольск-на-Амуре";

3 - Амурский муниципальный район;

4 - Аяно-Майский муниципальный район;

5 - Бикинский муниципальный район;

6 - Ванинский муниципальный район;

7 - Верхнебуреинский муниципальный район;

8 - Вяземский муниципальный район;

9 - Комсомольский муниципальный район;

10 - Нанайский муниципальный район;

11 - Николаевский муниципальный район;

12 - Охотский муниципальный район;

13 - муниципальный район имени Лазо;

14 - муниципальный район имени Полины Осипенко

15 - Советско-Гаванский муниципальный район;

16 - Солнечный муниципальный район;

17 - Тугуро-Чумиканский муниципальный район;

18 - Ульчский муниципальный район;

19 - Хабаровский муниципальный район.

Задача 3. Известно, что по маршруту между Комсомольском-на-Амуре и Хабаровском ходят четыре автобуса. Два из них окрашены в жёлтый цвет, один в красный и ещё один - в синий. Автобус какого цвета следующий подойдёт к автовокзалу - неизвестно. Какое количество информации мы получим, когда увидим цвет подъехавшего автобуса?

Задача 4. Как изменится размер файла с растровым изображением географической карты Хабаровского края (приводятся фотографии изображений карты), если изначально количество кодируемых цветов было 65536, а после преобразования стало 256?

Задача 5. В открытом ежегодном чемпионате Хабаровского края по велогонкам участвуют 119 спортсменов. Специальный технический прибор регистрирует момент прохождения каждым участником промежуточного финиша, фиксируя его номер с использованием минимального необходимого количества битов, одинакового для каждого из спортсменов. Каков информационный объём сообщения, записанного устройством, после прохождения промежуточного финиша 70-ю велосипедистами?

Задача 6. Перевести количество городских поселений Хабаровского края 1314 из системы счисления с основанием 4 в десятеричную систему.

Задача 7. Перевести количество сельских поселений Хабаровского края 18810 из десятеричной системы счисления в пятеричную (с основанием 5).

Задача 8. Перевести год образования Хабаровского края 79216 из шестнадцатеричной системы счисления в восьмеричную.

Задача 9. Расположение мостов в г. Хабаровске в 2050-х годах показано на рисунке ниже. Можно ли прой- 
ти каждый мост ровно по одному разу и вернуться в исходную часть города?

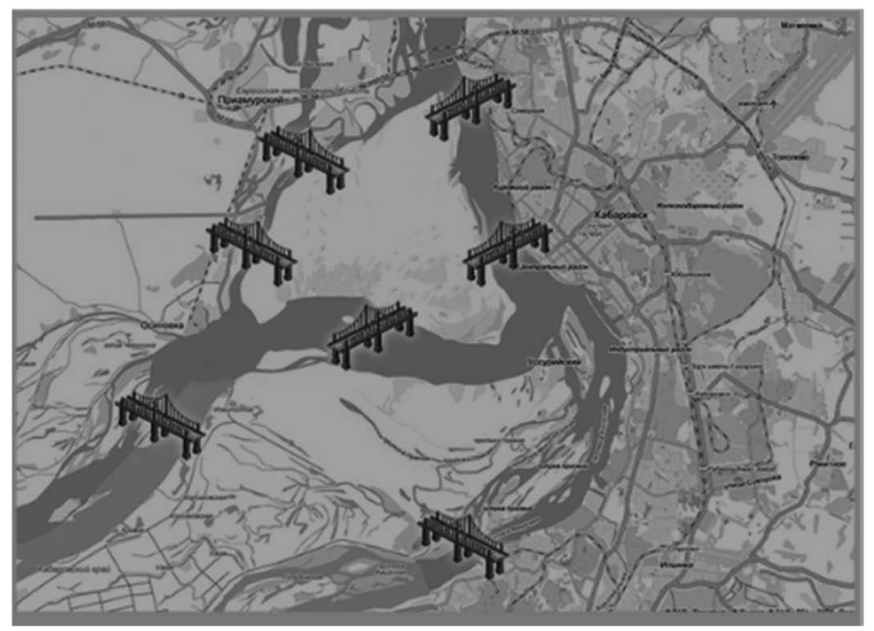

Использование этих и других задач и заданий из пособия апробировано на занятиях по информатике в Хабаровской краевой заочной физико-математической школе и ряде общеобразовательных организаций Хабаровского края. Результаты внедрения подтверждают повышение интереса обучающихся не только к информатике и ИКТ, но и другим общеобразовательным предметам учебного плана.

В развитие проводимой работы по регионализации содержания образования в Хабаровском крае перед старшекурсниками педагогического института ФГБОУ ВО "Тихоокеанский государственный университет", изучающими информатику, поставлена задача формирования банка данных задач по информатике с региональным содержанием для активизации познавательной деятельности студентов младших курсов и школьников Хабаровского края.

\section{ЛИТЕРАТУРА}

1. Реализация регионального компонента общего образования в условиях ФГОС 00: сборник методических материалов / Отв. ред. Г.Н. Паневина. Хабаровск: ХК ИР0,2017 - 104 с.

2. Сайт Интернет-магазина "еТор" [Электронный ресурс]. - Режим доступа: http://etop.portalkhv.ru/?p=63 (дата обращения: 11.01.2021).

3. Депозитарий электронных изданий Научно-технического центра "Информрегистр" [Электронный ресурс]. - Режим доступа: http://catalog.inforeg.ru/Inet/ GetEzineBylD/305494 (дата обращения: 11.01.2021).

4. Петроглифы Сикачи-Аляна [Электронный ресурс]. - Режим доступа: https://ru.wikipedia.org/wiki/\%D0\%9F\%D0\%B5\%D1\%82\%D1\%80\%D0\%BE\%D0\%B3\% D0\%BB\%D0\%B8\%D1\%84\%D1\%8B_\%D0\%A1\%D0\%B8\%D0\%BA\%D0\%B0\%D1\%87\%D0\%B8-\%D0\%90\%D0\%BB\%D1\%8F\%D0\%BD\%D0\%B0 (дата обращения: 11.01.2021).

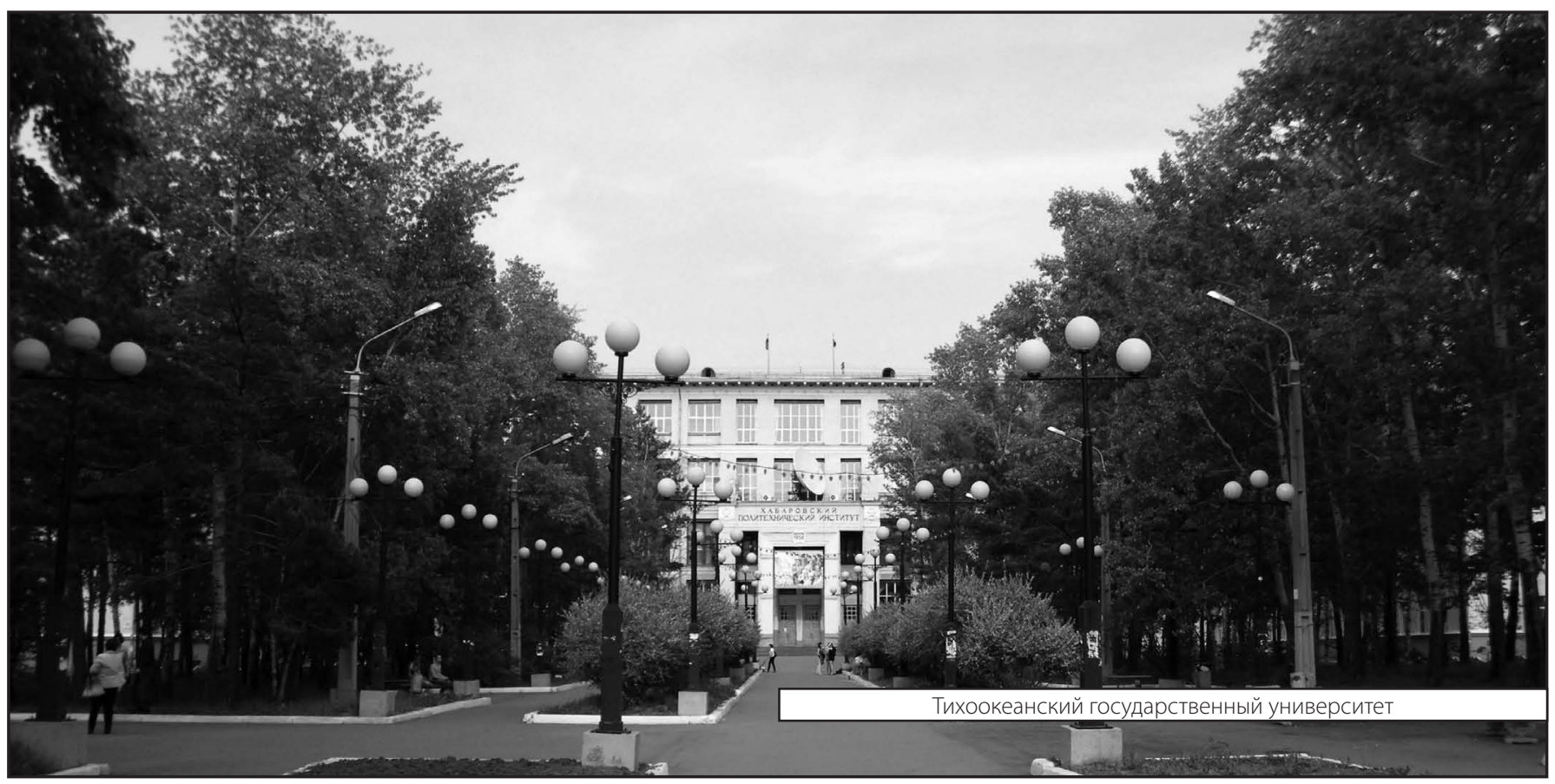

